Bangladesh J. Bot. 42(2): 195-206, 2013 (December)

\title{
SILVER FERNS OF BANGLADESH AND THE EXCLUSION OF REPORTED ALEURITOPTERIS GRISEA (BLANF.) PANIGRAHI (PTERIDOPHYTA, PTERIDACEAE)
}

\author{
CR FRASER-JENKINS ${ }^{1 *}$ \\ Student Guest House, Thamel, P.O. Box no. 5555, Kathmandu, Nepal
}

Key words: Silver Ferns, Aleuritopteris anceps, A. grisea, A. subdimorpha, Bangladesh, Myanmar

\begin{abstract}
The three species of Aleuritopteris ("Silver Ferns") present in Bangladesh are discussed, A. bicolor (Roxb.) Fraser-Jenk, A. anceps (Blanf.) Panigrahi and A. subdimorpha (C.B.Clarke \& Baker) Fraser-Jenk., correcting some previous erroneous reports. Aleuritopteris grisea (Blanf.) Panigrahi has recently been reported from the Chittagong Hills, S.E. Bangladesh. But that species is well known to be a high Himalayan Sino-Himalayan species of the Tibetan subtype, confined to the main Himalayan ranges and occurring from c. 2900 - $4000 \mathrm{~m}$ altitude. The specimen misreported as it from Bangladesh belongs to the low-altitude species, A. anceps (Blanf.) Panigrahi, which occurs from c. 300-750 m altitude and is a S.E. Asian (Malesian) element in the flora of the Indian subcontinent. This species was first knowingly collected in Bangladesh in the same District in 2003 by the present author, but unfortunately Bangladesh was then inadvertently omitted from its range in his monographic summary of Indian subcontinental cheilanthoid ferns.
\end{abstract}

\section{Introduction}

Aleuritopteris Fée is a distinctive segregate genus of small cheilanthoid ferns in Family Pteridaceae, which are commonly known as "Silver ferns" due to the attractive white, or sometimes yellow flavonoid farina beneath the lamina. The large and compound genus Cheilanthes Sw., contains a number of discrete groups, which though fairly easily recognisable, are difficult to circumscribe. But several of them are also supported moleculo-cladonomically, including Aleuritopteris Fée, which was first brought into current usage by Ching (1941) and many others in China and is now more widely accepted internationally. Like most cheilanthoid genera it is difficult to define and find hard-and-fast diagnostic characters due to the variable morphology of different members of the genus. It includes both farinose and efarinose species and while the character of wider segments may separate it to some degree from some other Asian cheilanthoid genera, such as Cheilanthes Sw. (including Cheilosoria Trevis. and Mildella C.C.Hall \& Lellinger), it is easier to delimit it by the related species that are clearly members of it, utilising intuitive taxonomic placement of species. Molecular data helps greatly with this process but does not provide characters to summarise the distinctness of the genus in some attempted "definition", and it is also becoming increasingly clear, despite the recent practice of many workers, that it cannot by itself dictate decisions as to whether to recognise a group at generic or subgeneric rank, in the absence of any morphological considerations.

In the Indian subcontinent quite a large number of 20 species of Aleuritopteris Fée occur (Khullar 1994, Fraser-Jenkins 1997, 2008, Fraser-Jenkins and Dulawat 2009), being adjacent and connected to the centre of evolutionary diversity of the genus in S.W. China. But due to their generally similar appearance, many species are widely misidentified and often remain in confusion, even though once one knows the diagnostic scale-characters to look for, the species are actually rather easy to separate and identify accurately, with a few exceptions.

*Author for correspondence: <chrisophilus@yahoo.co.uk>. ${ }^{1}$ Address: Research Fellow, The Royal Botanic Garden, Edinburgh, UK. 
Recently Mirza et al. (2006) reported the occurrence of A. grisea (Blanf.) Panigrahi from lowaltitude S.E. Bangladesh, not realising that this species is a purely high-altitude Tibetan-type SinoHimalayan species, occurring from c. 2800-4000 m altitude and could not possibly be present in the subtropical forest of Bangladesh, among all the S.E. Asian/Malesian pteridophytes of that area. The misidentification may have been compounded by Panigrahi's (1957, 1960, 1961, 1998), Panigrahi and Dixit's (1966), Panigrahi et al. (1969), Dixit's (1984, 1997) and Dixit and Kala's (1986) now well known confusion of A. grisea (Blanf.) Panigrahi, among other species, mainly with A. formosana (Hayata) Tagawa, but also with A. bicolor (Roxb.) Fraser-Jenk., and thus erroneous reporting of it from C. India etc. Recent misidentification of specimens (restudied by the present author in CAL) and erroneous illustration of the majority of species of the genus under wrong names by Ghosh et al. (2004) may also have contributed to its confusion. This case demonstrates well the importance of developing accurate knowledge of the species before preparing to publish an apparently major taxonomic account, such as by Ghosh et al. (2004), in order to avoid misleading other workers in the region. In addition the report by Mirza et al. (2006) was evidently made in some isolation since none of the authoritative modern works on the genus was cited (e.g. Verma and Khullar 1965, Khullar 1994, Fraser-Jenkins 1997, 2008), nor even the older but generally accurate work of Blanford $(1886,1888)$ and Hope $(1900)$, while the genus was placed in the erstwhile Family Sinopteridaceae (Sinopteris Ching \& C.Chr. being a synonym of Aleuritopteris Fée), instead of Pteridaceae subfam. Cheilanthoideae (see Fraser-Jenkins 2010).

Until then, earlier botanists (Clarke 1880, Beddome 1883, Hope 1900, Prain 1903, Sinclair 1956) had either not come across any species of Aleuritopteris Fée or (Clarke 1880) recorded only "Cheilanthes farinosa" (Forssk.) Kaulf. from Bangladesh. But since no material of Aleuritopteris Fée from Bangladesh is represented in the collections at K, K-W, BM, E, CAL and DACB, it is difficult to ascertain which species Clarke's record from Chittagong referred to. But it has become widely known in recent decades that true A. farinosa (Forssk.) Fée is actually a distinct species somewhat close to A. anceps (Blanf.) Panigrahi, but confined to S. Arabia and Africa (mainly in N.E. Africa) and does not occur in the Indian subcontinent, including Bangladesh, at all. Following the discovery of the cytological difference between African A. farinosa (Forssk.) Fée and the Indian plant by Manton and Sledge (1954), Manton et al. (1966), Verma and Loyal (1960) and Verma and Khullar (1965) (Fraser-Jenkins 1997: 68-69, for a summary), Fraser-Jenkins (1992, 1993, 1997) and Fraser-Jenkins and Dulawat (2009) separated them morphologically as well, and established that the correct name for the common and widespread lower-altitude Indiansubcontinental species Blanford had referred to "C. farinosa var. typica" from Simla (Himachal Pradesh) is A. bicolor (Roxb.) Fraser-Jenk. (syn.: Cheilanthes bicolor (Roxb.) Griff. ex FraserJenk.).

A. bicolor (Roxb.) Fraser-Jenk. occurs in Bangladesh in the North-East (Sylhet), near the border with Meghalaya State, India, and is scattered in the North-West, adjacent to West Bengal State, India. It also occurs in the further South-East (Hazarikhil; Barayadala). Possibly this species was reported from the Chittagong Hills by Mirza and Rahman (1997) under the name A. farinosa (Forrsk.) Fée, but in their sense that name also included the very different, though also white-farinose, adventive species, originally from C. and S. America, Pityrogramma calomelanos (L.) Link (Gias \& Fraser-Jenkins, in prep.).

A related report was made from the Chittagong Hills by Pasha and Chakraborty (1982) under the mistaken identity of A. albomarginata (C.B.Clarke) Ching, which is another rather highHimalayan species (c. 1800-2700 m. or more), which again does not occur in Bangladesh. The present author has not examined the collection concerned, but it is certain that it could not be A. albomarginata (C.B.Clarke) Ching. 


\section{Identification of species reported}

Unfortunately considerable confusion is indicated by Mirza et al's. (2006) contrasting comparison between what she referred to as "A. albomarginata" and "A. grisea", which was incorrect in every feature mentioned and largely incomprehensible, while failing to mention any of the well publicised diagnostic features of those species. They stated the following points of distinction:

1. "A. albomarginata (C.B.Clarke) Ching is a spreading herb, whereas A. grisea (Blanf.) Panigrahi is a tufted herb with dimorphic frond". However both those species and also A. anceps (Blanf.) Panigrahi have a similar short, erect rhizome with spreading leaves arising from its apex and there is no difference at all in their growth habit. Neither A. grisea (Blanf.) Panigrahi nor A. anceps (Blanf.) Panigrahi (the true identity of their plant) has dimorphic fronds as stated, though basal fronds are generally smaller and lower than later ones, whereas A. albomarginata (C.B.Clarke) Ching actually does have dimorphic fronds, with tall, nearly, or completely efarinose Summer fronds and wider segments than the compact, basal Winter fronds, which are white-farinose and more scaly. Had they perhaps been thinking of $A$. bicolor (Roxb.) Fraser-Jenk., while mentioning A. albomarginata (C.B. Clarke) Ching, that, too, is non-dimorphic.

2. "Sterile stipe is hairy in A. albomarginata (C.B.Clarke) Ching, but in A. grisea (Blanf.) Panigrahi hairy only on the adaxial side of the stipe". This inexplicable statement does not apply to the genus Aleuritopteris Fée as the stipes are not hairy in any member of this genus, despite their further description of their plant as having the "stipe densely hairy on the adaxial side throughout". All stipes of ferns (apart from some non-Indian Marsilea L. species) are of course sterile, including in this genus. The only member of Pteridaceae occurring in the northern half of the Indian subcontinent that complies with their comment is Cheilanthes nitidula Hook. (syn.: Mildella nitidula (Hook.) C.C.Hall \& Lellinger), which has dense, small, black hairs confined to the upper surface of the rachis and costae, though not actually on the stipe, but this Indo-Himalayan species is not known from or near to Bangladesh.

Had they meant scales instead of hairs their comment would still not apply. Perhaps the only possible explanation might have been a chance growth of mould on the top surface of the stipe, or the observation might have come from some old literature-description not pertaining to these species.

3. "Fertile stipe of A. albomarginata (C.B.Clarke) Ching is hairy, but fertile stipe of A. grisea (Blanf.) Panigrahi is smooth and black." While attempting to allow for possible misunderstanding of terms, particularly the term stipe (the stem below that supports the rachis and lamina), it is not possible for the present author to decipher what this cryptic statement could have referred to, unless they meant to say scales, not hairs, unlikely though that may seem. It is true to say that there are more scales running all the way up the stipe, rachis and costae in A. albomarginata (C.B.Clarke) Ching, but confined to near the base in A. grisea (Blanf.) Panigrahi, but neither species is present in Bangladesh. Furthermore, if they were comparing two of the species of this genus occurring in Bangladesh, A. bicolor (Roxb.) Fraser-Jenk. (sub albomarginata (C.B.Clarke) Ching) and A. anceps (Blanf.) Panigrahi (sub A. grisea (Blanf.) Panigrahi), then the situation would be the opposite as A. grisea (Forssk.) Fée is slightly more extensively scaly than $A$. bicolor (Roxb.) Fraser-Jenk., though in both the scales are confined to near the base of the stipe. If, perhaps, they were meaning the white farinaceous glands instead of hairs, their distribution on the stipe is merely a matter of age, a few being present in very young fronds, but deciduous and falling off later in both species.

4. "Sori are continuous and not powdery mass in A. albomarginata (C.B.Clarke) Ching, whereas sori are discontinuous and powdery mass in A. grisea (Blanf.) Panigrahi". Unfortunately this 
final statement is also incorrect, as the sori vary in all Aleuritopteris Fée species from being discontinuous when a frond is only weakly fertile, to continuous around the margin of each lobe or pinnule when more fully fertile. The "powdery mass" presumably refers to when the sporangia are most prominent when fully ripe and dehiscing, as opposed to immature - in all species of the genus.

It is evident that Mirza et al. (2006) had insufficient knowledge of the Bangladeshi species of Aleuritopteris and were unaware of the authoritative explanatory literature that could have informed them accurately about the genus. Despite the present author's having determined all the pteridophyte specimens at DACB herbarium some years ago, and having communicated detailed replies to a number of identity-queries from Mirza over some years, their report reveals a state of confusion about the genus, which therefore needs to be revised to avoid misleading future workers in the region.

\section{Aleuritopteris Fée species in Bangladesh}

The present author has studied pteridophytes on only four occasions in Bangladesh since 1990, twice around Sylhet and Madhubkunda in the north-east, and twice around Chittagong, Cox's Bazaar and the Chittagong Hill Tracts. But he has also worked in detail through the world's main herbaria containing Bangladeshi material, including re-identifying, listing and photographing all the extensive material in Kew (K), BM, Kolkata (CAL), as well as in Dhaka (DACB, DACU), Chittagong University and detailed study over many years in all UK and other European mainland herbaria and in the main N. American herbaria. As a result an accurate knowledge of Bangladeshi pteridophyes, including Aleuritopteris Fée could be built up. The genus Aleuritopteris Fée is also one he has made a particular study of and revised over the years (along with Dryopteris Adans., Polystichum Roth, Athyrium Roth, Diplazium Sw. and Pteris L.), including from Bangladesh.

Three species of Aleuritopteris Fée have been found so far in Bangladesh, A. bicolor (Roxb.) Fraser-Jenk., the much rarer $A$. anceps (Blanf.) Panigrahi (both low-altitude species as would be expected, but the former also extending higher into the Himalaya) and lastly A. subdimorpha (C.B.Clarke \& Baker) Fraser-Jenk., which is a lower-mid to mid-altitude species centered in Myanmar and the N.E. Indian Hills, but extending west to C. Nepal. The latter was tentatively reported from Bangladesh by Fraser-Jenkins and Dulawat (2009) and is confirmed here. These three are treated and compared diagnostically below, along with brief comparison with the other two species reported in error from the country.

1. Aleuritopteris bicolor (Roxb.) Fraser-Jenk. in Fraser-Jenkins \& Dulawat, Fern Gaz. 18(5): 223 (2009); Tax. Rev. Three Hundred Indian Subcont. Pterid. Rev. Census List: 126 (2008); type from "Mts. N. of Rohilkund" (Uttarakhand, N.W. India) [BR!].

(Fig. 1A)

Synonyms: Pteris bicolor Roxb., in Griffith, Calcutta J. Nat. Hist. 4: 507 (1844); Cheilanthes bicolor (Roxb.) Griff. ex Fraser-Jenk., Pakistan Syst. 5(1-2): 94 (1992 ["1991"]); Bot. Helvetica 102(2): 144 (1993 ["1992"]); New Sp. Syndrome Indian Pterid. Ferns Nepal: $68-72$ (1997); Khullar, Illustr. Fern Flora W. Himalaya 1: 192-193, t. 72 [t. 72 sub C. dalhousiae [err. for dalhousieae] Hook. in error, apart from wide scales drawn] (1994), excl. t. 69 [= A. leptolepis (Fraser-Jenk.) Fraser-Jenk. from the Indo- and Chinese Himalaya]; Thapa, Pterid. Nepal: 64 (2002). Including the misprint "C. discolor" of Griffith [sphalm.] (treated as if distinct by Saiki 1984).

Cheilanthes farinosa (Forssk.) Kaulf. var. tenera C.B.Clarke \& Baker, J. Linn. Soc., Lond. 24: 411 (1876); type from Khasia, River Khiri, 2500 ft. (in Meghalaya, N.E. India) [K!]. 
Aleuritopteris kathmanduensis Ching \& S.K.Wu, in Wu, Act. Bot. Yunnan. 5(2): 167 (1983); type from Sundarijal, Kathmandu (E.C. Nepal) [KYO, apparently lost; type locality and area studied in detail].

Misapplied names: Cheilanthes farinosa sensu auct. Ind. plur., Hooker (1858, p.p.); Beddome (1883, p.p.), Blanford (1886, 1888), Clarke (1880, p.p.), Hope (1900), Ching (1941) sub var. farinosa, Dixit (1984, p.p.), non (Forssk.) Kaulf. [from Yemen; and widespread in Africa]

Aleuritopteris pulveracea sensu Saiki (1984), Punetha \& Kholia (1989); Nakaike, Matsumoto \& Gurung (1990), non (C.Presl) Fée [nom. superfl. for A. argyrophylla (Sw.) Fée, from Africa].

Aleuritopteris stenochlamys, A. doniana, A. platychlamys and A. pseudofarinosa sensu S.R. Ghosh, in Ghosh et al. (2004), non Ching \& S.K.Wu [= A. stenochlamys from the C. and E. IndoHimalaya and S.W. China]; non S.K.Wu [= A. dealbata Fée from the C. and E. Indo-Himalaya and S.W. China]; non Ching [= A. grisea from the Indo-Himalaya and China] and non Ching \& S.K.Wu [= A. anceps (Blanf.) Panigrahi, see below], respectively.

The name refers to the bicolorous scales, not the obvious green laminar top-surface and white lower surface as might be imagined.

Diagnostic description: Stipe thin, often purplish-brown, usually as long as or longer than the lamina, scales confined to the stipe-base, very narrow $(4 \mathrm{~mm}$. $\times$ less than $1 \mathrm{~mm}$.), bicolorous, with a narrow dark streak along the centre and contrasting pale edges; lamina thin, widely deltatepentagonal, the lowest pinnae much the longest and widest, with very long lowest basal basiscopic pinnules, 2/3 to sometimes nearly as long as the pinna; farina beneath fairly bright white, but not rarely rather thin or weak [note that the farina of Aleuritopteris Fée etc. is often lost in Indian region herbaria due to the necessary dipping or brushing with mercuric chloride in alcohol as an insecticide, and is also damaged by heat-drying, when it sticks to the paper and comes off the lamina]. Low and mid to upper-mid altitude (c. 300-1800 m.). Present in Bangladesh.

Range: W. Africa (Nigeria); Pakistan; W., N., C. and S. India (Rajasthan; Punjab; Jammu \& Kashmir; Himachal Pradesh; Uttarakhand; Uttar Pradesh; Darjeeling; Sikkim; Arunachal Pradesh; Assam; Nagaland; Manipur; Meghalaya; Tripura; Mizoram; Jharkand; Madhya Pradesh; Maharashtra; Orissa; Andhra Pradesh; Karnataka; Kerala; Tamil Nadu); W., C. and E. Nepal; Bhutan; N.W. and N.E. Bangladesh; Sri Lanka; ?S.W. China; Myanmar; Thailand; Laos.

Ecology: Throughout most of its range it is a very common species of walls, banks and on earth in open rocky places, often completely drying up in the Winter and losing many leaves; with a surprisingly wide altitude-range from $c$. 200-1800 m.

Cytotype: Diploid sexual; variously reported as having a base-number of $n=29$, or $n=30$, so probably requiring confirmation from more specimens from various areas.

Specimens examined: Hazarikhil, Syed Hadiazzaman 98, 29.1.1962 (DACU), det. CRFJ 27.5.1997; Hajarikhil, A.A. Khan 54, 2.1.1962 (DACU), det. CRFJ, 9.2.1992 and 27.5.1997; on the way to Hazarikhil, Shamser Rahman 8, 29.1.1962 (DACU), det. CRFJ 9.2.1992 and 27.5.1997; Barayadala, A. Ahmed 1014 (DACU), det. CRFJ, 27.5.1997.

2. Aleuritopteris anceps (Blanf.) Panigrahi, Bull. Bot. Surv. India 2: 321 (1961); Wu, Act. Phytotax. Sinica 19(1): 70-71 (1981), non sensu Wu [= A. formosana (Hayata) Tagawa, see below]; Ghosh et al., Pterid. Flora East. India 1: 404-405 (2004), but altitude far too high and identity uncertain; Saiki, J. Phytogeog. Taxon. 32(1): 3 (1984); Fraser-Jenkins, Tax. Rev. Three Hundred Indian Subcont. Pterid. Rev. Census List: 565, 566 (2008); Fraser-Jenkins \& Dulawat, Fern Gaz. 18(5): 222 (2009). Lectotype of Cheilanthes anceps Blanf., J. Simla Nat. Hist. Soc. 25: 6 (1886) (here designated): "Cheilanthes anceps Blanf. Jumna Valley, opposite Lokwah, 5000 to 5500 ft., coll. H.F. Blanford, 1886. Herb G. King", CAL (in Uttarakhand, N.W. India).

(Fig. 1B) 
Synonyms: Cheilanthes anceps Blanf., J. Simla Nat. Hist. Soc. 25: 6 (1886); Beddome, Handb. Ferns Brit. India Suppl.: 21 (1892); Hope, J. Bombay Nat. Hist. Soc. 13: 249 (1900); Dixit, Census Indian Pterid.: 63 (1984); Khullar, Illustr. Fern Fl. W. Himalaya 1: 188-192, (1994), but with cytotype given incorrectly as diploid and scales drawn up rhachis in t. 68, as in a large A. formosana (Hayata) Tagawa; Fraser-Jenkins, Pakistan Syst. 5(1-2): 95, 108 (1992 ["1991"]); New Sp. Syndr. Ind. Pterid. Ferns Nepal: 68-71, 76 (1997); Thapa, Pterid. Nepal: 64 (2002); Cheilanthes farinosa var. anceps (Blanf.) Blanf., J. Asiat. Soc. Bengal 57: 301 (1888); Aleuritopteris farinosa var. anceps (Blanf.) Ching, Hongkong Naturalist 10: 201 (1941), non sensu Ching p.p. max. [= A. formosana (Hayata) Tagawa, see below].
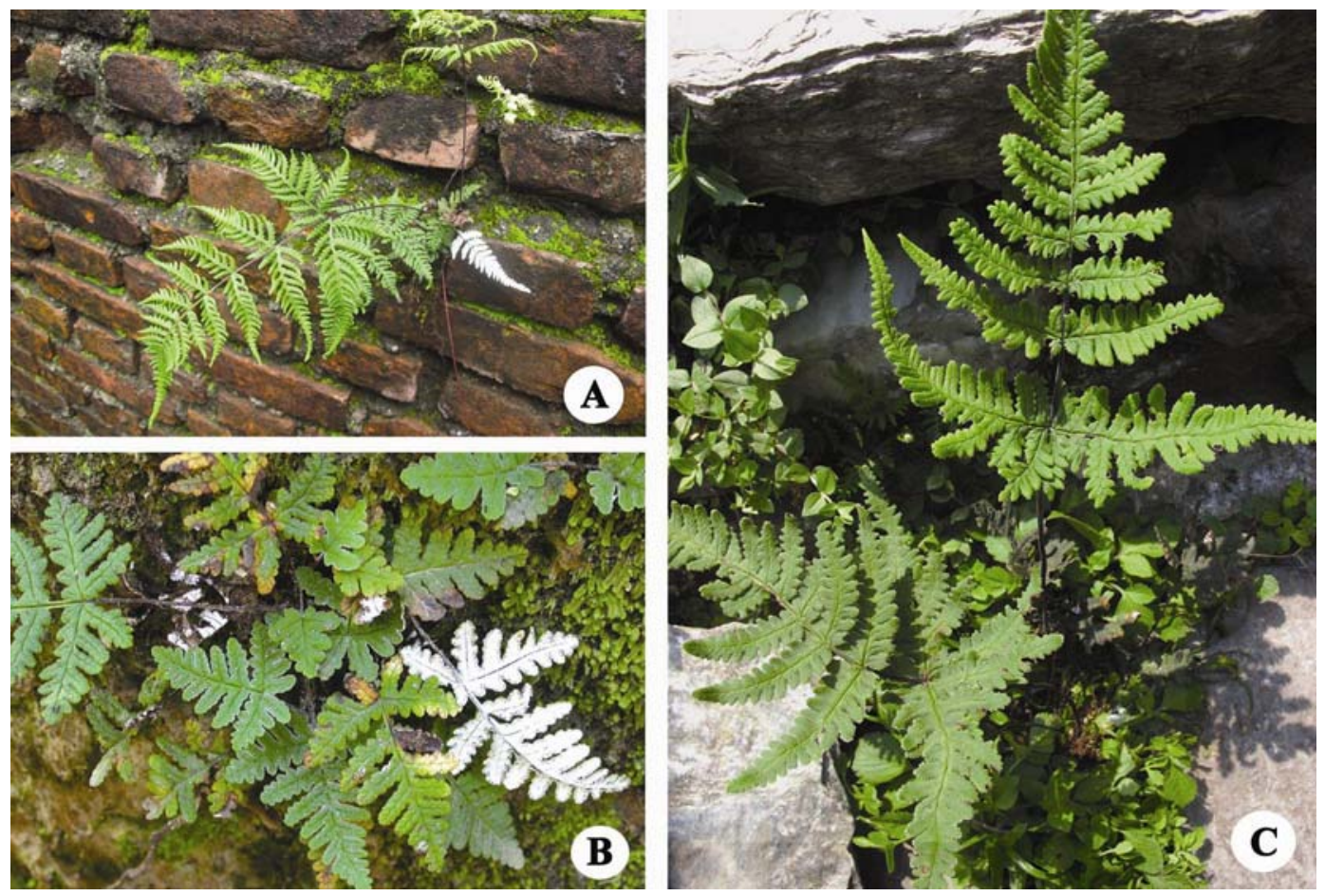

Fig. 1 A-C. A. Aleuritopteris bicolor (Roxb.) Fraser-Jenk. - Nepal, C., Bagmati Zone, Kathmandu District, between Naya Bazaar and Maephi Hill, on old wall, c. 1550 m, C.R. Fraser-Jenkins, 25.10.2011 [specimen not collected]. B. Aleuritopteris anceps (Blanf.) Panigrahi - Bangladesh, S.E., Chittagong Hill Tracts District, way to Boga Lake, Ruma Jilla, c. 400 m, C.R. Fraser-Jenkins 30256, 1 Jan. 2004 (K, E) (see above). C. Aleuritopteris subdimorpha (C.B.Clarke \& Baker) Fraser-Jenk. - Nepal, C., Gandaki Zone, Kaski District, between Jinu and New Bridge, way to Annapurna Base Camp from the south, at base of large boulder, c. 1600 m, C.R. Fraser-Jenkins, J.C.B. Fraser-Jenkins \& Sagun Pariyar Field no. 350, 6 June 2012 (TAIF).

Cheilanthes candida Zoll., Nat. Gen. Arch. Neerland. Ind. 2: 203 (1845), non M.Martens \& Galeotti (1842). Type from Java [L!].

Aleuritopteris pseudofarinosa Ching \& S.K.Wu, Act. Phytotax. Sinica 19: 72 (1985); Ghosh et al., Pterid. Flor. E. Himalaya: 401-404 (2004), non sensu Ghosh [= A. bicolor (Roxb.) FraserJenk.]. Type from Yunnan, S.W. China [PE!]. 
Aleuritopteris interrupta Saiki, J. Phytogeogr. Taxon. 32(1): 5 (1984). Type from N. Thailand [KYO!].

Aleuritopteris javanensis Saiki, J. Phytogeogr. Taxon. 32(1): 7 (1984), non Cheilanthes javanensis (Willd.) T.Moore. Type from Java [KYO!].

Misapplied name: Cheilanthes mexicana sensu Punetha \& Kholia (1989), non (Fée) Punetha \& Kholia [from Mexico], comb. illeg., nec Davenp. [from Mexico]

Diagnostic description: Stipe thick, jet black, usually c. 1/2 to 2/3 the length of the lamina, scales mostly distributed in the lower half of the stipe, but smaller ones running up to the top of the stipe, occasionally one or two very small ones on the lower rachis, medium-wide and rather long $(5 \mathrm{~mm} \times 1.5+\mathrm{mm})$, bicolorous, with a dark streak along the centre, and the scale-apices often rather darker than the bases; lamina thick, elongated-deltate, the lowest pinnae gradually the longest, and their lowest basiscopic pinnule the longest, but not markedly longer than the rest as in A. bicolor (Roxb.) Fraser-Jenk., c. 1/3 to half as long as the pinna; farina beneath thick, bright intense white. Low and lower-mid altitude (c. 300-1200 m). Present in Bangladesh.

Range: Pakistan; W., N., C. and S. India (Rajasthan; Punjab; Jammu \& Kashmir; Himachal Pradesh; Uttarakhand; Darjeeling; Sikkim; Orissa; Madhya Pradesh; Maharashtra; Karnataka; Kerala; Tamil Nadu); W., C. and E. Nepal; Bhutan; S.E. Bangladesh; S. China (Rare: Yunnan; Kwangtung); Myanmar; Sri Lanka; Thailand; Java; Timor. Reported from Tibet and Taiwan in error by Fraser-Jenkins and Dulawat (2009). Over-reported from China and by Chinese botanists in error for A. formosana (Hayata) Tagawa.

Ecology: A fairly common low-altitude species (at the lower, not the upper limit of A. bicolor (Roxb.) Fraser-Jenk., as stated by Khullar (1994) due to confusion with A. formosana (Hayata) Tagawa), commonest in the outer foothills of the west Indo-Himalaya, often appearing on steep river-bank cliffs and usually a lithophyte, with an altitude range from $300 \mathrm{~m}$. - c. $900 \mathrm{~m}$.

Cytotype: Tetraploid sexual, $n=58$; base-number, $x=29$ (has sometimes been reported erroneously in India as diploid sexual with $n=30$, in error for $A$. formosana (Hayata) Tagawa).

Specimens examined: Excluding Clarke's unidentified report of "A. farinosa", non (Forssk.) Kaulf., from Chittagong, this species was apparently first collected in Bangladesh in 1962, misidentified as C. farinosa (Forssk.) Kaulf. (Hazarikel, Md. A. Zahid 5, 28.1.1962 (DACU), det. CRFJ, 27.9.1997). If the Chittagong collection referred to by Pasha \& Chakraborty (1982), sub A. albomarginata (C.B.Clarke) Ching, was also A. anceps (Blanf.) Panigrahi, this would be a second collection. It was then collected and identified in the field as A. anceps (Blanf.) Panigrahi, by the present author (S.E. Bangladesh, Chittagong Hill Tracts District, up stream valley leading from Ruma S.S.E. up to Boga Lake, S. of Bandarban, Ruma Jilla, Banderban Sub-District, S.E. of Chittagong, among rocks and densely, naturally forested slopes, on a large boulder near stream, $c$. 400 m. C.R. Fraser-Jenkins 30256, 1 Jan. 2004 (K), with Mohammad Chowdhury of Bangladesh Ecotours, Chittagong, and Robert Bawm, of Ruma). Lastly Mirza et al's. (2006) collection from 2005 (Bandarban, Roangchari, Muhammad Nur-E-Alam \& Rezina Ahmed s.n., 15.11.2005 (DACB)) has been reidentified here from the illustration and its bicolorous scales as A. anceps (Blanf.) Panigrahi.

3. Aleuritopteris subdimorpha (C.B.Clarke \& Baker) Fraser-Jenk., in Fraser-Jenkins \& Dulawat, Fern Gaz. 18(5): 223 (2009); Tax. Rev. Three Hundred Indian Subcont. Pterid. Rev. Census List: 126, 566 (2008) [as a comb. inval.]. Name omitted by Ghosh et al. (2004). Type from the Khasi Hills, Shillong (Meghalaya, N.E. India) [K!].

(Fig. 1C)

Synonyms: Cheilanthes farinosa (Forssk.) Kaulf. var. subdimorpha C.B.Clarke \& Baker, J. Linn. Soc., Lond. 24: 411 (1888); Beddome, Suppl. Ferns Brit. India, Ceylon Malay Penins.: 2122 (1892); Cheilanthes subdimorpha (C.B.Clarke \& Baker) B.K.Nayar \& S.Kaur, Comp. Bedd. 
Handb.: 26 (1974) [authorities "(C.B.Clarke \& Baker) Hieron." were given by Fraser-Jenkins (2008) and thence Fraser-Jenkins \& Dulwat (2009), but this appears to have been some in error]; Dixit, Census Ind. Pterid.: 65 (1984); Fraser-Jenkins, New Sp. Syndr. Indian Pterid. Ferns Nepal: 75-76 (1997); Chandra, Ferns India: 57 (2000) [excl. erroneous Garhwal locality].

Aleuritopteris longipes Ching \& S.K.Wu, in Wu, Act. Bot. Yunnan. 5(2): 165-167 (1983); Ghosh et al., Pterid. Flora E. India: 395, 397 (2004); Cheilanthes longipes (Ching \& S.K.Wu) R.D.Dixit \& Bal Krishna, in Trivedi, M.L., Gill, B.S. \& Saini, S.S. (eds.), Plant Sci. Res. in India: 10 (1989). Type from Kurseong, below Darjeeling, H. Hara et al. s.n., 12.4.1960 (KYO, apparently lost; isotype TI!) (in West Bengal, N.C. India). The citation of "Hara et al." for the specimens cited by Wu before the type-specimen may be carried forward to apply to the type specimen as well, which was otherwise not properly cited and would make the name invalid. This name was erroneously extrapolated to be A. bicolor (Roxb.) Fraser-Jenk. by Fraser-Jenkins (1997) in the absence of the type from KYO, without record, but perhaps loaned to PE or Kunming.

Aleuritopteris pentagona Saiki, J. Phytogeog. Taxon. 32(1): 8 (1984), non Cheilanthes pentagona Schelpe \& N.C.Anthony. Type from N. Thailand [KYO!].

Aleuritopterus pseudoargentea S.K.Wu, Mem. Fac. Sci. Kyoto Univ., Biol. 8(2): 155-15 (1983); Cheilanthes pseudoargentea (S.K.Wu) K.Iwats., in Smitinand, T. \& Larssen, K. (eds.), Fl. Thailand 3(4): 619 (1989). Type from N. Thailand [KYO!].

Misapplied name: Cheilanthes farinosa sensu Hooker (1858), p.p., non (Forssk.) Kaulf. [from Yemen and Africa].

Diagnostic description: Stipe thick, very robust and stiff (unless in small immature plants), ebony black, characteristically very long, usually up to twice as long as the lamina, scales confined to the stipe-base and slightly above, lanceolate, slightly wide at their bases, with narrow, attenuated apices ( $5 \mathrm{~mm} . \times 1.5 \mathrm{~mm}$.), concolorous, yellowish red (though some on the rhizome or at the point where the stipe arises may be darker reddish with a blackish centre), easily detached and lost; lamina markedly short, thick, widely deltate, the lowest pinnae much the longest and widest, with a very long lowest basal basiscopic pinnule that is usually outwardly curved-falcate, $2 / 3$ as long as the pinna, pinnule lobes crowded and compact, not very deeply cut; farina beneath bright white, thick. Lower to upper-mid altitude (c. 400-1800 m.+). Present in Bangladesh at the lowest limit of its altitude range.

Range: C. and E. Nepal (rare); N. and N.E. India (Uttarakhand (rare); Darjeeling; Sikkim (rare); Arunachal Pradesh; Nagaland; Manipur; Meghalaya; Assam State; Mizoram); Bhutan; Bangladesh; Myanmar; Thailand; S.W. and S. China; Laos; Vietnam.

Specimens examined: Hajarikhil, Zia Uddin Ahmed 20, 31.1.1962 (DACU), det. CRFJ, 27.5.1997; ?Dawki, S.K. Sen \& R. Khan s.n., 1.5.1941 (DACU), det. CRFJ, 27.5.1997. Although Dawki town itself is within Meghalaya State of India, adjacent to the international border, the specimen being preserved in Dhaka University, might perhaps have come from the Bangladesh side of the present border.

Specimens of A. dealbata Fée (syn.: C. doniana Fraser-Jenk. \& Khullar), labelled "Pundooah mont., F. de Silva, Wallich Cat. 71/3 (BM!, K-W! etc.)" are not from Bangladesh, but from well up in the Khasi Hills, Meghalaya India, where it occurs, and it cannot be expected in Bangladesh itself. Although Pandua is along the river shortly N.E. of Sylhet in the plains in Bangladesh, De Silva's collections labelled "mont." (Mountains) are known to be from the Khasi Hills to the north, and not Bangladesh (Fraser-Jenkins 2006).

Apart from erroneous reports of A. farinosa (Forssk.) Kaulf., the other two species mistakenly reported from Bangladesh are A. albomarginata (C.B.Clarke) Ching and A. grisea (Blanf.) Panigrahi, both higher-altitude, Himalayan species that do not occur in or near the Country. Five 
common and widespread Indian species, including the above species and A. formosana (Hayata) Tagawa (also not known from Bangladesh), have a white farina beneath the lamina, though $A$. albomarginata (C.B.Clarke) Ching usually produces efarinose and nearly efarinose fronds during the Summer monsoon season. The remaining three species can be distinguished as follows:

1. A. albomarginata (C.B.Clarke) Ching: Stipe medium-thin, black or sometimes slightly purplish, usually c. 2/3 the length of the lamina, scales distributed throughout the stipe, rachis and costae and sometimes costules as well, more numerous on the small, basal Winter fronds with white farina, than on the large, nearly or completely efarinose. Summer fronds, narrow (c. $4 \mathrm{~mm} \times 1 \mathrm{~mm}$ ), bicolorous, with a dark streak along the centre and pale edges; lamina thick, dimorphic and very variable in size and dissection, from small, white-farinose basal fronds with small lobes, to large, tall efarinose or very weakly farinose fronds with wide lobes, the latter rapidly turning brown with the onset of Winter. Upper-mid altitude (c. 1800 $2700 \mathrm{~m}$ ), on rock-surfaces. Not present in Bangladesh.

2. Aleuritopteris grisea (Blanf.) Panigrahi, non sensu Panigrahi (syn.: A. platychlamys Ching, non sensu Fraser-Jenkins (1997) [= A. stenochlamys Ching \& S.K.Wu]): Stipe thin, rather delicate, red-brown, usually as long as or longer than the lamina except in very small plants, scales present towards the basal part, easily rubbed off and semi-deciduous, ovate to ovatelanceolate, small (to $3 \mathrm{~mm} \times 2 \mathrm{~mm}$ ), \pm dark red, some on the rhizome apex with a central black streak, but those on the stipe obviously concolorous and uniform red; lamina fragile or brittle, elongated-deltate, the lowest pinnae slightly and gradually the longest, and their lowest basiscopic pinnule c. 1/3 as long as the pinna, upper surface markedly wrinkled and bullulate; farina beneath thick powdery white, with a good smattering of powder on the stipe and uppersurface as well in younger fronds. High altitude (2800 - 4000+ m), among rocks. Not present in Bangladesh.

One other common species, not known from Bangladesh, may usefully be detailed:

3. Aleuritopteris formosana (Hayata) Tagawa (syn.: Cheilanthes brevifrons (Khullar) Khullar): Stipe rather thin, black, usually much shorter than the lamina, with scattered white farinaceous glands here and there, mainly in the upper half of the stipe, with scales scattered throughout and small ones present throughout most of the rachis, but not on pinna-costae, lanceolate, smaller and narrower than in A. anceps (Blanf.) Panigrahi (to $3 \mathrm{~mm}$. $\times 1 \mathrm{~mm}$.), bicolorous, with a narrow dark streak along their centres; lamina lanceolate, the lowest pair of pinnae usually slightly shorter than, or the same length as the next pair above, and their lowest basiscopic pinnule $c$. 1/3 as long as the pinna, upper surface markedly wrinkled and bullulate; farina beneath thick powdery white. Plant smaller than the related A. anceps (Blanf.) Panigrahi, with fronds usually only up to $c .10-15 \mathrm{~cm}$. long, though more sheltered plants can have fronds up to $c .20 \mathrm{~cm}$. long; forming more of a compact rosette of many fronds, often lying more or less flat against a wall or between stones on earth banks. Abundant in a zone at upper-mid altitude $(c .1300-2000 \mathrm{~m})$. Diploid sexual, $n=30$. Not present in Bangladesh. Throughout the outer ranges of the Indo-Himalaya and extending further south to Rajasthan, Madhya Pradesh and Maharashtra, as a rarity. This is also the common member of the A. anceps (Blanf.) Panigrahi group in China, where it has long been known under that name in error, while $A$. anceps (Blanf.) Panigrahi itself is considerably uncommon there, with A. formosana (Hayata) Tagawa extending across S. China to Taiwan and Luzon in the north Philippines, also present in W. Africa.

\section{Variation within Aleuritopteris anceps (Blanf.) Panigrahi}

A. anceps (Blanf.) Panigrahi in an older, broader sense is a complex of two species, the first is the true A. anceps (Blanf.) Panigrahi, as recognised by Blanford and described above, though some of Blanford's identifications in CAL, BM and K reveal that he had slightly mixed concepts, 
but the identity of the name is now fixed by lectotypification in the sense he mainly used, as followed widely in India. The second is the smaller, narrower-fronded and more widespread species, A. formosana (Hayata) Tagawa, described above. Ching (1941), followed by all Chinese pteridologists, unfortunately misapplied the epithet anceps to A. formosana (Hayata) Tagawa, and subsequently Ching \& Wu redescribed true $A$. anceps (Blanf.) Panigrahi, which is rather rare and little known in China, as A. pseudofarinosa Ching \& S.K.Wu. A. formosana (Hayata) Tagawa was first tentatively separated as a smaller form of A. anceps (Blanf.) Panigrahi in India by Hope (1900) and then more definitively in 1965 by Verma, as "C. himaliae" S.C.Verma \& Chand Sharma, ined., in Sharma's Ph.D. thesis at Panjab University. Verma's finding was followed by Khullar (1976, 1985), eventually under the name Cheilanthes brevifrons (Khullar) Khullar. It was also found by them to be diploid with $n=29$, while A. anceps (Blanf.) Panigrahi has been reported as both diploid and tetraploid, due to confusion, but is actually tetraploid with $n=58$. The frondand scale-morphology of true $A$. anceps (Blanf.) Panigrahi is exactly intermediate between $A$. formosana (Hayata) Tagawa and A. dealbata Fée and an obvious course of further investigation would be to set up hybridisation experiments in the classic Mantonian way, leading to genomeanalysis, which has never yet been done for any pteridophyte in the Indian region, despite its great interest and informativeness.

Putting aside A. formosana (Hayata) Tagawa, plants of A. anceps (Blanf.) Panigrahi from S.E. Bangladesh have not yet been investigated cytologically. But the present author has noticed that $A$. anceps (Blanf.) Panigrahi in Myanmar, where he studied it in the south-east near Kyaiktyo, Mon State, in 2006, often appears to have a slightly wider and shorter lamina than in many IndoHimalayan and S. Indian plants. It also tends to have slightly less obvious darker central stripes in the scales in some plants, though always present to some degree. The difference, however, is very subtle, and many plants of $A$. anceps (Blanf.) Panigrahi are quite identical in morphology between Myanmar and the Indo-Himalayan foothills. Occasionally some Myanmar plants seem to veer slightly towards A. bicolor (Roxb.) Fraser-Jenk. in lamina-width, while still obviously being $A$. anceps (Blanf.) Panigrahi in the more important features of scale-width and distribution, stipecolour and its relative length and thickness, bright white farina etc. It was for this reason that the Chittagong Hills plant was initially misreported by Fraser-Jenkins and Dulawat (2009) under A. bicolor (Roxb.) Fraser-Jenk., but stated there as being towards A. anceps (Blanf.) Panigrahi - when it should have been the other way around, as the author soon realised. The Chittagong plant also appears more similar to the Myanmar ones. Quite what, if anything, this very slight difference means, is difficult to interpret, but it seems most likely to be no more than slight geographical clinal variation and not to indicate an aggregate. Nevertheless it would be of value to investigate the Bangladesh plant cytologically for confirmation. In addition chemical analysis of the flavonoids in the farina would be useful, as Prof. E. Wollenweber has found in an extensive programme of analysis at Darmstadt Technical University of the author's and others' collections (Wollenweber \& Fraser-Jenkins, ined.) that the species of Aleuritopteris Fée all have characteristic and distinctive combinations of flavinoids, specific to each species, confirming the distinctness of A. formosana (Hayata) Tagawa (the Himalayan and Taiwan material being identical), A. anceps (Blanf.) Panigrahi and A. bicolor (Roxb.) Fraser-Jenk., which are all markedly distinct and discrete, though the series of A. albomarginata (C.B.Clarke) Ching, A. dubia (C.Hope) Ching and A. rufa (D.Don) Ching are perhaps rather surprisingly identical to each other, while being different from all other species. Though the author has sent various material of A. anceps (Blanf.) Panigrahi from Myanmar and Bangladesh to Wollenweber, further work has no longer been possible on them due to circumstances. Material of Nepalese and Indian Aleuritopteris Fée for an ongoing extensive programme of molecular work has also been included in a detailed study by E.A. Hooper at Missouri and it is to be hoped that it may cast further light on this interesting genus. 


\section{Acknowledgments}

The author is most grateful to Abdul Ali, Monaf Ali and Teraban Bibi of Bishwanath, Sylhet, and Oxford, for their help while he was in Sylhet, and to Dr. Mohammad Gias Uddin, of Chittagong University and Toronto, and especially to Prof. M.K. Pasha of Chittagong University for his kind help in Chittagong and the Hill Tracts, as also to Mohammad Chowdhury and Didar of Bangladesh Ecotours, Chittagong. He is also grateful to Drs. M.M. Rahman and Momtaz M. Mirza for assistance while he worked through DACB herbarium, Dhaka, and to Prof. S.P. Khullar, Panjab Univ., Chandigarh, for drawing the author's attention in 2012 to the report of A. grisea (Blanf.) Panigrahi from Bangladesh. Assistance and full access to the herbaria at Dhaka University (DACU), Kolkata (CAL), Shillong (ASSAM), Kew (K), London (BM), Edinburgh (E) and Washington DC (US) is gratefully acknowledged. He is especially grateful for the kind personal assistance of Dr. Peter J. Edwards to enable him to work at the Royal Botanic Garden, Kew, in 2013, and of Dr. Henry J. Noltie and Prof. Mary Gibby, to enable him to work at the Royal Botanic Garden, Edinburgh, in 2012-3, and of Alison Paul, to enable him to work at BM in 2013, and acknowledges with gratitude grants from the Sibbald Trust, R.B.G.E., and the Trustees of the Natural History Museum, London.

\section{References}

Beddome RH 1883. Handbook to the Ferns of British India, Ceylon and the Malay Peninsula. Thacker Spink \& Co., Calcutta. pp. 501.

Blanford HF 1886. The Silver ferns of Simla and their allies. J. Simla Naturalists Soc. 2: 13-22.

Blanford HF 1888. A list of the ferns of Simla in the N.W. Himalaya between levels of 4,600 and 10,500 ft. J. Asiat. Soc. Bengal 57: 294-315.

Chandra S 2000. The Ferns of India (Enumeration, Synonyms \& Distribution). International Book Distributors, Dehra Dun. pp. 459.

Ching RC 1941. The studies of Chinese ferns 31. Hong Kong Naturalist 10(3-4): 194-204.

Clarke CB 1880. A review of the ferns of Northern India: with an index of the species and 36 plates. Trans. Linn. Soc. (Lond.), ser. 2 Bot., 1: 425-619.

Dixit RD 1984. A census of the Indian Pteridophytes. Flora of India, ser. 4. Botanical Survey of India, Howrah. pp. 177.

Dixit RD 1997. Pteridophyta. In: Saxena HO and Brahman M (Eds), The flora of Orissa 4: 2009-2918.

Dixit RD and Kala K 1986. The Silver ferns of Madhya Pradesh. Proc. Indian Sci. Congr. (Part 4) 73: 70.

Fraser-Jenkins CR 1992 ["1991"]. The ferns and allies of the far west Himalaya. Pakistan System. 5(1-2): 85-120.

Fraser-Jenkins CR 1993 ["1992"]. The ferns and allies of the far west Himalaya - Some additions and corrections. Botanica Helvetica 102(2): 143-157.

Fraser-Jenkins CR 1997. New species syndrome in Indian Pteridology and the ferns of Nepal, and two Errata. International Book Distributors, Dehra Dun. pp. 403.

Fraser-Jenkins CR 2006. The first botanical collectors in Nepal, The fern collections of Hamilton, Gardner and Wallich - lost herbaria, a lost botanist, lost letters and lost books, somewhat rediscovered. Bishen Singh Mahendra Pal Singh, Dehra Dun. pp. 106.

Fraser-Jenkins CR 2008. Taxonomic revision of three hundred Indian Subcontinental Pteridophytes with a revised census-list, A new picture of fern-taxonomy and nomenclature in the Indian subcontinent. Bishen Singh Mahendra Pal Singh, Dehra Dun. pp. 685.

Fraser-Jenkins CR 2010 ["2009"]. A brief comparison of modern Pteridophyte classifications (Families and Genera in India). Indian Fern J. 26(1-2): 107-131.

Fraser-Jenkins CR and Dulawat CS 2009. A summary of Indian cheilanthoid ferns and the discovery of Negripteris (Pteridaceae), an Afro-Arabian fern genus new to India. Fern Gaz. 18(5): 216-229.

Ghosh SR, Ghosh B, Biswas A and Ghosh RK 2004. Leptolepidium and Aleuritopteris. In: The Pteridophytic flora of Eastern India. Flora of India, ser. 4, 1: [1-] 384-404 [-591]. Botanical Survey of India, Kolkata.

Gias MU and Fraser-Jenkins CR in prep. A revised annotated checklist of the Pteridophytes of Bangladesh. 
Hooker WJ 1858. Species Filicum [etc.] 2: 77-78. William Pamplin, Soho Square, [London].

Hooker WJ and Baker JG 1865-1868. Synopsis Filicum, or a synopsis of all known ferns etc., Robert Hardwicke, Picadilly, London. pp. 482.

Hope CWW 1900. Cheilanthes. In: The ferns of north-western India, Including Afghanistan, the Trans-Indus Protected States, and Kashmir: arranged and named on the basis of Hooker and Baker's Synopsis Filicum, and other works, with new species added. J. Bombay Nat. Hist. Soc. 13(2): 242-251 [and 12(3): 528-529, et tt. 1899].

Khullar SP 1976. Some lesser known ferns from the W. Himalayas 1. Cheilanthes anceps var. brevifrons. Amer. Fern J. 66: 21-24.

Khullar SP 1985 ["1984"]. The Ferns of Western Himalaya: A few additions, corrections and annotations. Indian Fern J. 1(1-2): 89-96.

Khullar SP, with Fraser-Jenkins CR 1994. Cheilanthes. In: An illustrated fern flora of West Himalaya 1: [1-] 180-216 [-506]. International Book Distributors, Dehra Dun. [2: 1-544. 2000].

Manton I and Sledge WA 1954. Observations on the cytology and taxonomy of the pteridophyte flora of Ceylon. Phil. Trans. Roy. Soc. Lond., Biol., 238: 127-185.

Manton I, Roy SK and Jarrett F 1966. The cytotaxonomy of some members of the Cheilanthes farinosa complex in Africa and India, Kew Bull. 18(3): 553-565.

Mirza MM and Rahman MM 1997. An annotated check list of ferns and fern-allies of Bangladesh. Bangladesh J. Plant Taxon. 4(2): 47-69.

Mirza MM, Siddiquee MN and Ahmed R 2006. Aleuritopteris grisea (Blanford) Panigrahi: a new pteridophyte record for Bangladesh. Bangladesh J. Plant Taxon. 13(2): 173-175.

Nakaike T, Matsumoto S and Gurung VL 1990. Distribution Maps of Pteridophytes in Kathmandu, Nepal (3). In: Watanabe M and Malla SB (Eds), Cryptogams of the Himalayas 2 Central and Eastern Nepal: 187-212. National Science Museum, Tsukuba.

Panigrahi G 1957 ["1955"]. The gametophyte of Aleuritopteris grisea (Blanford) comb. nov. Proc. Nat. Inst. Sci. India 21: 143-146.

Panigrahi G 1960. Pteridophytes of the Eastern India 1. Enumeration of the species collected and their nomenclature. Bull. Bot. Surv. India 2(3 \& 4): 309-314.

Panigrahi G 1961 ["1960"]. A note of Aleuritopteris grisea (Blanford) Panigrahi comb. nov., and A. anceps (Blanford) Panigrahi comb. nov. Bull. Bot. Surv. India 2: 321-322.

Panigrahi G 1998. Pteridophytic flora of Orissa. Plant. Sci. Res. (Orissa) 20(1 \& 2): 1-45.

Panigrahi G and Dixit RD 1966. New Records of ferns for Madhya Pradesh. Proc. Nat. Acad. Sci. Ind. Allahabad 36: 222-233.

Panigrahi G, Singh AN and Misra OP 1969. Contribution to the botany of the Tarai Forests of the Bahraich District of Uttar Pradesh. Bull. Bot. Surv. India 11(1 \& 2): 89-114.

Pasha MK and Chakraborty R 1982. Ferns of Bangladesh 2. Chittagong Univ. Stud. Part 2 (Sci.) 2(6): 71-95.

Prain D[D] 1903. Bengal Plants 2: 1237-1270. Government of India, Calcutta.

Punetha N and Kholia BS 1989. Additions to the pteridophytic flora of Pithoragarh District of Kumaon (West Himalaya). New Botanist 16(1-4): 115-126.

Saiki Y 1984. Notes on ferns 2. Asiatic species of the Aleuritopteris farinosa complex. J. Phytogeog. Taxon. 32(1): 1-13.

Sinclair J 1956 ["1955"]. The Flora of Cox’s Bazar, East Pakistan. Bull. Bot. Soc. Bengal 9(2): [84-] 114-115 [-116].

Verma SC and Khullar SP 1965. Cytology of some W.-Himalayan Adiantaceae (sensu Alston) with cytotaxonomic comments. Caryologia 18(1): 85-106.

Verma SC and Loyal DS 1960. Chromosome counts in some ferns from Nainital. Curr. Sci. 29: 69-70.

Wollenweber E and Fraser-Jenkins CR in prep. The chemotaxonomy of the genus Aleuritopteris in the Indian subcontinent.

(Manuscript received on 28 August, 2012; revised on 8 June, 2013) 